\title{
Supporting plant diversity and conservation through landscape planning: A case study in an agro-tourism landscape in Tampusu, North Sulawesi, Indonesia
}

\author{
FABIOLA B. SAROINSONG ${ }^{\vee}$ \\ Faculty of Agriculture, Universitas Sam Ratulangi. Kampus Unsrat, Bahu, Manado 95115, North Sulawesi, Indonesia. Tel. +62-431-863886. \\ `email: fabiolabsaroinsong@gmail.com
}

Manuscript received: 8 October 2019. Revision accepted: 21 March 2020

\begin{abstract}
Saroinsong FB. 2020. Supporting plant diversity and conservation through landscape planning: a case study in an agrotourism landscape in Tampusu, North Sulawesi, Indonesia. Biodiversitas 21: 1518-1526. Plants are one of the living elements of a landscape which have dynamic characteristics. In the green/vegetation concept, the diversity of plants becomes vital in landscape planning to articulate the ecological, socio-cultural, and economic aspects in effort to mitigate biodiversity loss. The aim of this study is to illustrate the application of the green concept when planning an agro-tourism landscape in Tampusu region, North Sulawesi, Indonesia which demonstrates the function and utilization of plants in landscape management while paying attention to plant diversity. Data collection was conducted by field surveys, interviews, and literature studies. Data collected and analyzed included the existing conditions of site, site history, planning goal, topography, flora and fauna, climate, existing facilities and utilities, and area management. Based on its function, the green concept in landscape planning in Tampusu agro-tourism grouped plant diversity into four functions, namely production, ecological, architectural, and aesthetic functions. The ecological aspect of plant species selection (both existing species and added species) was based on the consideration of the plant's function in the landscape with special consideration of its contribution to plant diversity and conservation including those considered as endemic species. There are architectural function for examples Goodyera celebica, Racemobambos celebica, Ficus minahassae, Pterospermum celebicum, Diospyros celebica; ecological function for examples F. minahassae, Clerodendrum minahassae, Vatica celebica, Myristica minahassae, Diospyros minahassae, Korthalsia celebica, Licuala celebica, Aquilaria beccariana, Kibatalia wigmanii, Lithocarpus celebica; production function for examples Musa celebica, Musa acuminafe; aesthetic function for examples C. minahassae, Ixora celebica, D. celebica, R. celebica, Phalaenopsis celebensis. This study demonstrates that the application of the green concept in landscape planning can help to translate plant diversity and conservation into management actions, especially in agro-tourism landscape.
\end{abstract}

Keywords: Agro-tourism, landscape planning, plant diversity, plant selection, vegetation concept

\section{INTRODUCTION}

Biodiversity has important values including existence value, landscape services, inheritance, choice, consumptive, and productive (BAPPENAS 2004). Despite biodiversity has values important to human and environmental sustainability, the decline in biodiversity continues (Altieri 1999; Verburg et al. 2015). The main causes of the loss of biological diversity include habitat loss or degradation, pollution, alien invasive species, overharvesting of biodiversity resources, climate change, and homogenization of species in agriculture (Hens and Boon 2005; Budiharta et al. 2011; Verburg et al. 2015). Nonetheless, the common factor of all these causes is that they are human-driven.

Imboden et al. (2010) proposed that all biodiversity management should be guided by defined long-term goals and operational targets. As such, it is necessary to consider biodiversity systematically in all land-use planning and management. In the context of landscape planning, green concept is an important thing to consider when developing and building outdoor space (Wascher and Haines-Young 2009; Ahmadi, Sadeghi and Eskandarinezhad 2016). The green concept or vegetation concept or (landscape) plants concept is one of concepts used in landscape planning process, usually as a part of preliminary landscape plan. It is defined as general idea of plant management including the selection of species (either from those that already exist or those that will be added), their arrangement (general composition) and placement (not detail but zoning, general location), along with their functions in a landscape, to solving problems and taking advantage of the potential contained in the landscape.

Considerations in formulating the green concept include many things based on analysis of landscape characteristics and the purpose of landscape planning. The things considered then can be classified as ecological/ environmental aspects, socio-cultural aspects, and economic aspects. In the context of ecological/environmental aspects, management of plant biodiversity is one of the important issues at this time aimed to mitigate biodiversity loss which has serious implications including on food security (Bryan et al. 2010; Frison et al. 2011). Planning for biodiversity management and monitoring biodiversity benefits should always be considered in the broader landscape context, as well as 
analyzing social perspective in post-hoc land-use choices to assess economic or recreational opportunities for local stakeholders without compromising biodiversity targets that may have been set (Imboden et al. 2010; Sasaoka and Laumonier 2012; Ahmadi et al. 2016; Saroinsong and Kalangi 2017).

Agro-tourism is a worldwide trend, a type of tourism that has seen a boost in popularity within recent years. It is becoming an important tourism development opportunities. Inappropriate agro-tourism development causes environmental degradation. On the contrary, if planned and implemented properly can have a good impact on environmental management and rural area development (Muhammad et al. 2016). Agro-tourism can support new directions in rural sustainable development, with specific effects on the environment (Ciolac et al. 2019). Moreover, compared with farms without agro-tourism, agro-tourism tend to develop more environmentally friendly agricultural methods, which have a positive impact on biodiversity, landscape and natural resources (Mastronardi et al. 2015).

A study was conducted in a ranch area in Tampusu Village which was built in the 1980s. However, tourist attraction was limited and stagnant. There was no other tourist attraction developed in addition to its main attraction, and the area was only equipped with very limited facilities coupled with not optimal area management. Considering the various potentials existed in the site along with the benefits that can be obtained from agro-tourism as well as the alternative for tourist destinations, proper Tampusu agro-tourism landscape planning is therefore needed. The aim of this study is to illustrate the application of the green concept when planning an agro-tourism landscape in Tampusu region, North Sulawesi, Indonesia which demonstrates the function and utilization of plants in landscape management while paying attention to plant diversity. The scope of biological diversity in this case study includes species diversity and genetic diversity under species level (i.e. cultivar).

\section{MATERIALS AND METHODS}

\section{Study period and area}

This study was conducted between April and August 2019. The study location was Tampusu Village, Remboken Sub-district, Minahasa District, North Sulawesi Province, Indonesia (Figure 1). The study site had an extent of 12 ha and it is the first stage development area of Tampusu Agrotourism, and will be expanded in the next stage.

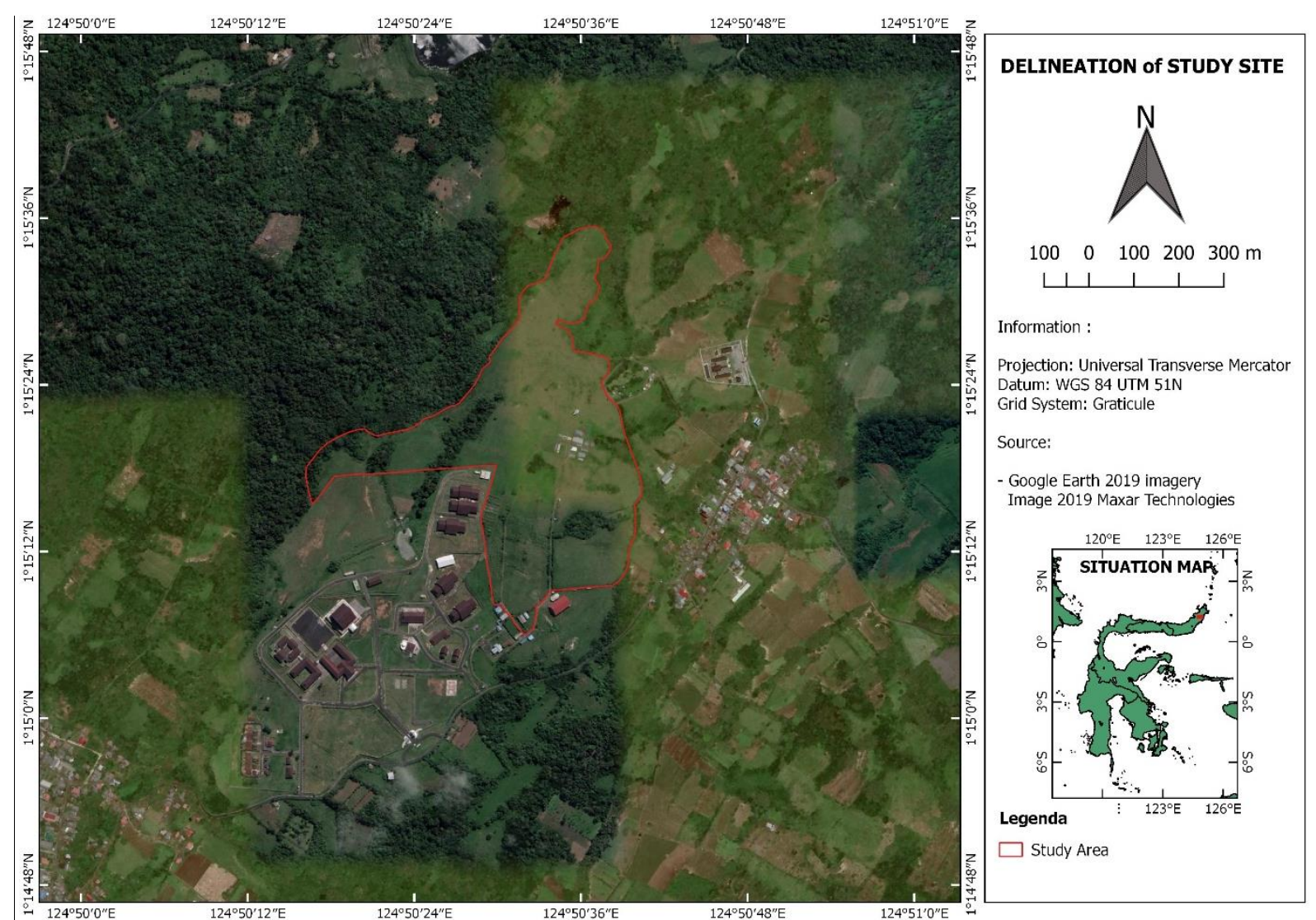

Figure 1. Map of study site in Tampusu Village, Remboken Sub-district, Minahasa District, North Sulawesi Province, Indonesia. Source: Google Earth 2019 imagery 


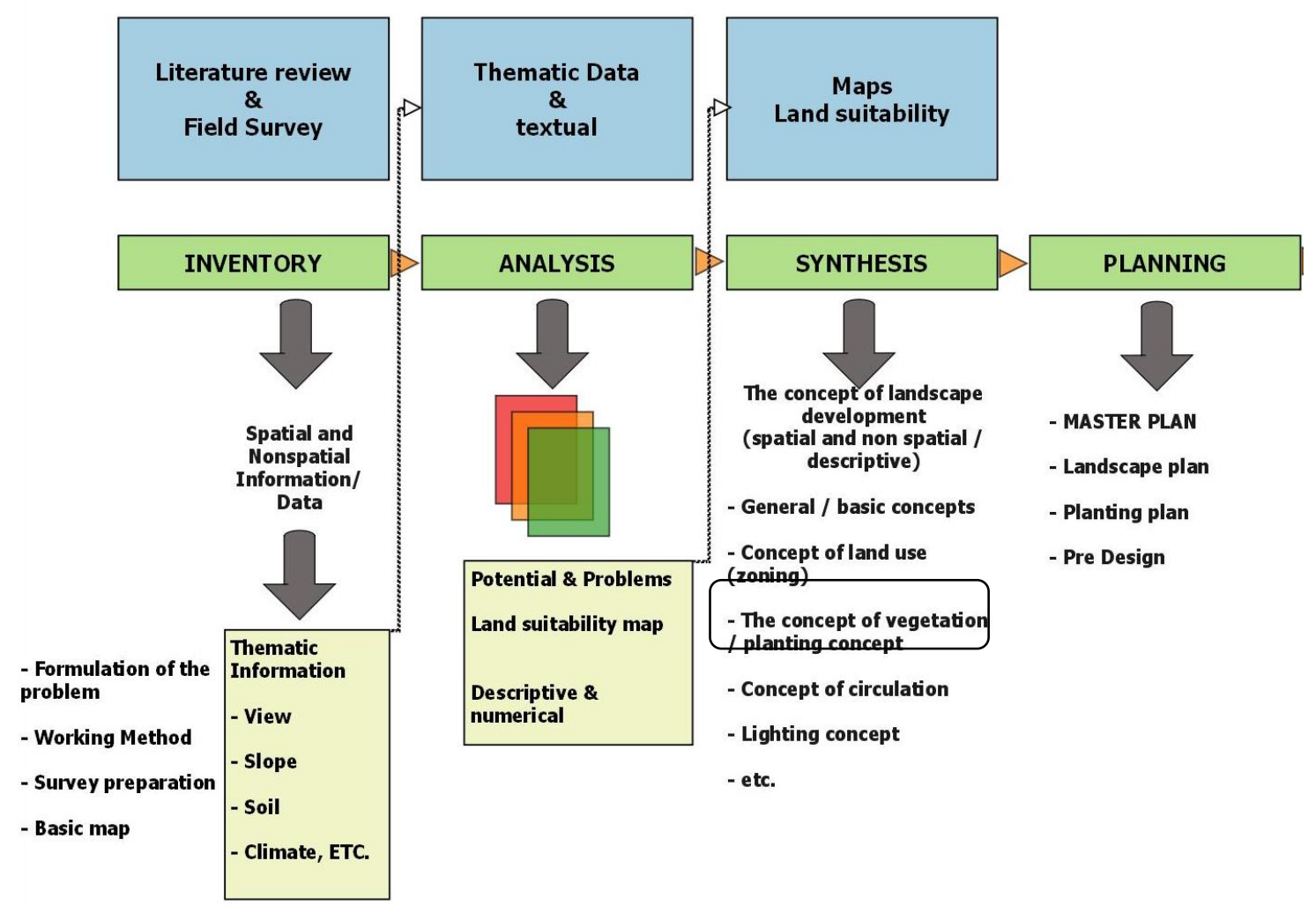

Figure 2. The framework of landscape planning applied in this study formulated based on the green concept

\section{Procedures}

This study was carried out following the landscape planning framework (Figure 2) and divided into three phases.

\section{Inventory phase}

Primary data collection activities were carried out through direct observation on the site, interviews with Head of Department of Agricultural, Animal Husbandry, and Fisheries, and the Tampusu Animal Husbandry Management Unit, and also field survey to collect data of site conditions, site history, planning goals, access, topography, scenery, flora and fauna, climate, facilities and utilities, and area management. Secondary data collection was carried out through information retrieval in the Tampusu Animal Husbandry Management Unit and scientific papers related to the topic of study.

\section{Analysis phase}

Analytical work was carried out on the collected data namely biophysical variables as well as socio-economic ones. This work was aimed to determine the potential and constraints that existed on the site and the results were analyzed descriptively and spatially.

\section{Synthesis phase}

The general concept of landscape planning was formulated and translated in more detailed concepts such as land use concept/space zoning, green/vegetation/plant concept, lighting concept, etc. This article highlights the green concept or vegetation concept, focusing on the use of plants in the landscape.

\section{Data analysis}

Data analysis was conducted descriptively and spatially. Computerized graphic techniques and Geographic Information System (GIS) was utilized in the analysis.

\section{RESULTS AND DISCUSSION}

\section{Overview of study location}

Site history and planning goal

The study location was located in Tampusu Village, Remboken Sub-district, Minahasa District, North Sulawesi Province, Indonesia. From the 1980s to the beginning of the 1990s, the study site had been developed as an area of cattle and horse farming which was quite famous for fresh milk production and a place with beautiful scenery and pleasant cool climate. Recently, the level of tourist visits has dropped dramatically compared to when it was first developed. Based on interviews with the Head of Department of Agricultural, Animal Husbandry, and Fisheries, and the Tampusu Animal Husbandry Management Unit, it was revealed that the planning goal of Tampusu agro-tourism is to develop an attractive and profitable agro-tourism area with potential selling points on the application of the management system of organic animal husbandry and organic agriculture. 


\section{Topography}

A contour map was made and analyzed (Figure 3 ). The result of the analysis of land slope classes (Table 1) showed that the site had several slope classes from flat to gently sloping topography (0-8\%), moderately sloping (8-15\%), rather steep (15-25\%), steep (25-45\%), and very step (> $45 \%$ ), with the most common were classified as moderately sloping and flat to gently sloping. When compared to areas that had relatively flat topography, the impression of this site was more dynamic but less stable. The main advantage of this non-flat topography was that the parts of the site were easier to be designed with different display characteristics, especially when supported by the use of other landscape elements. Constraints encountered included that in some parts of the site, the slope of the land can endanger livestock so that it requires design that limits the movement of livestock towards steep sections of the site. Topographical conditions of the site facilitate the regulation of rainwater drainage. But the threat that follows was, if land management and land cover were not carried out properly, then the site will easily experience erosion.

\section{Scenery}

In some parts, this site did not have a far point of view between the parts of the site due to the characteristics of the topography. But because it was located in the higher part of most of the surrounding areas, then the site had some potential points of view far beyond the site. Some interesting and beautiful sceneries were the views toward Mount Kasuratan, Mount Tampusu, and Lake Tondano which can be used to increase the attractiveness of the area. However, there was also a bad view towards the cemetery area which can be directly seen from the site that must be handled properly.

\section{Plants and animals}

The plants found on the site consisted of several species of trees, shrubs, and grass, including Arenga pinnata, Spathodea campanulata, Trema orientalis, Lagerstroemia speciosa, Bambusa sp., Datura metel, Hippobroma longiflora, Tagetes patula, Physalis peruviana, Clerodendron serratum, Cordyline fruticosa, Piper betle, Mikania micrantha, Amaranthus spinosus, Melastoma sp., Wedelia trilobata, Mimosa pudica, Ageratum conyzoides and Lopatherum gracile. Animals kept in the site were dairy cows, cows, and horses. In accordance with the plan of Tampusu agro-tourism, livestock to be raised are mainly dairy cows, and in addition to cows and horses.

Table 1. Land slope classes at the study site in Tampusu Village, Minahasa District, North Sulawesi Province, Indonesia

\begin{tabular}{lll}
\hline Land slope class & Description & Area $\left(\mathbf{m}^{\mathbf{2}}\right)$ \\
\hline $0-8 \%$ & Flat to gently sloping & 77301 \\
$8-15 \%$ & Moderately sloping & 111056 \\
$15-25 \%$ & Rather steep & 38666 \\
$25-45 \%$ & Steep & 25122 \\
$>45 \%$ & Very steep & 0 \\
Total & 252145 & \\
\hline
\end{tabular}

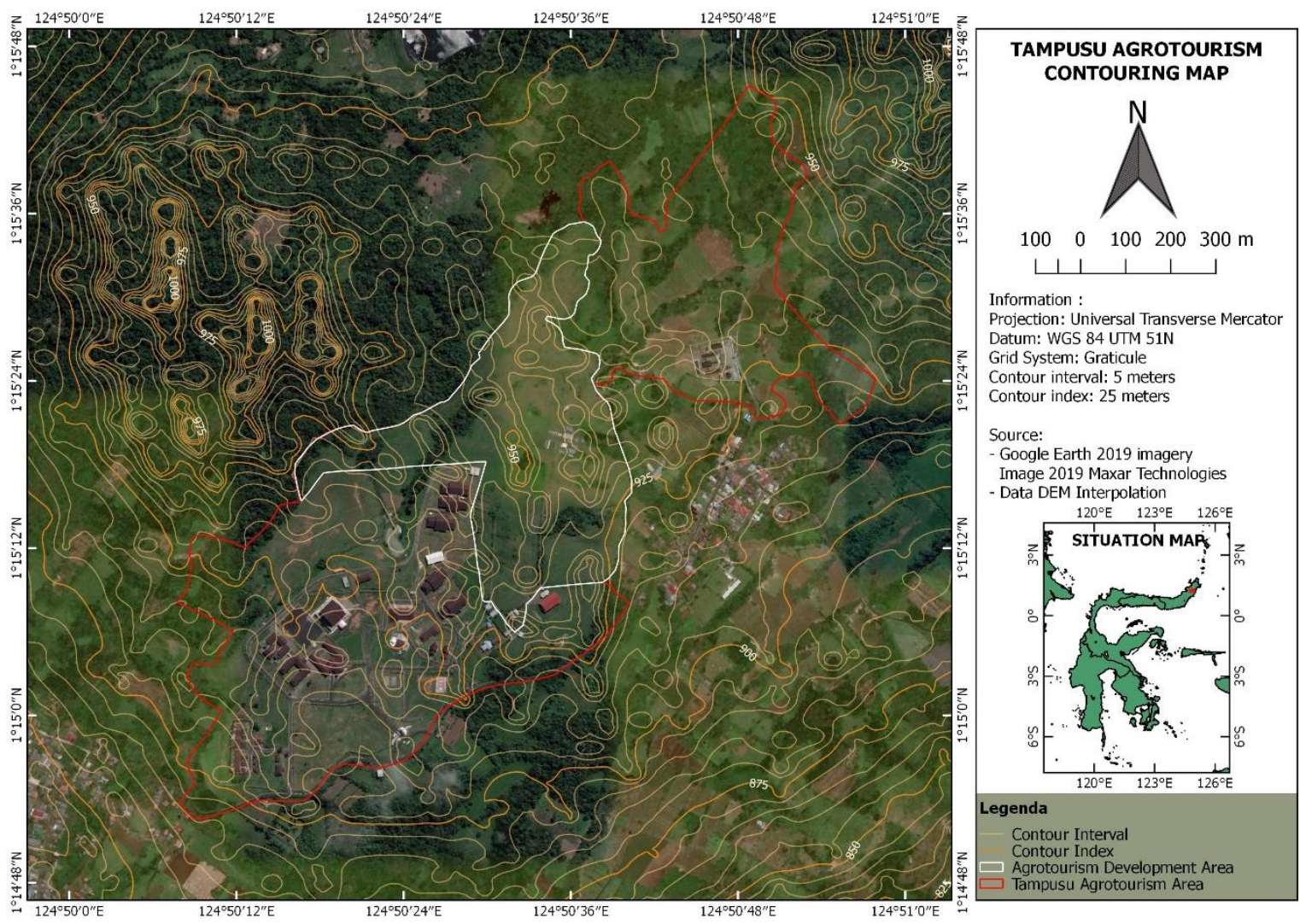

Figure 3. Countour map at the study site in Tampusu Village, Minahasa District, North Sulawesi Province, Indonesia 


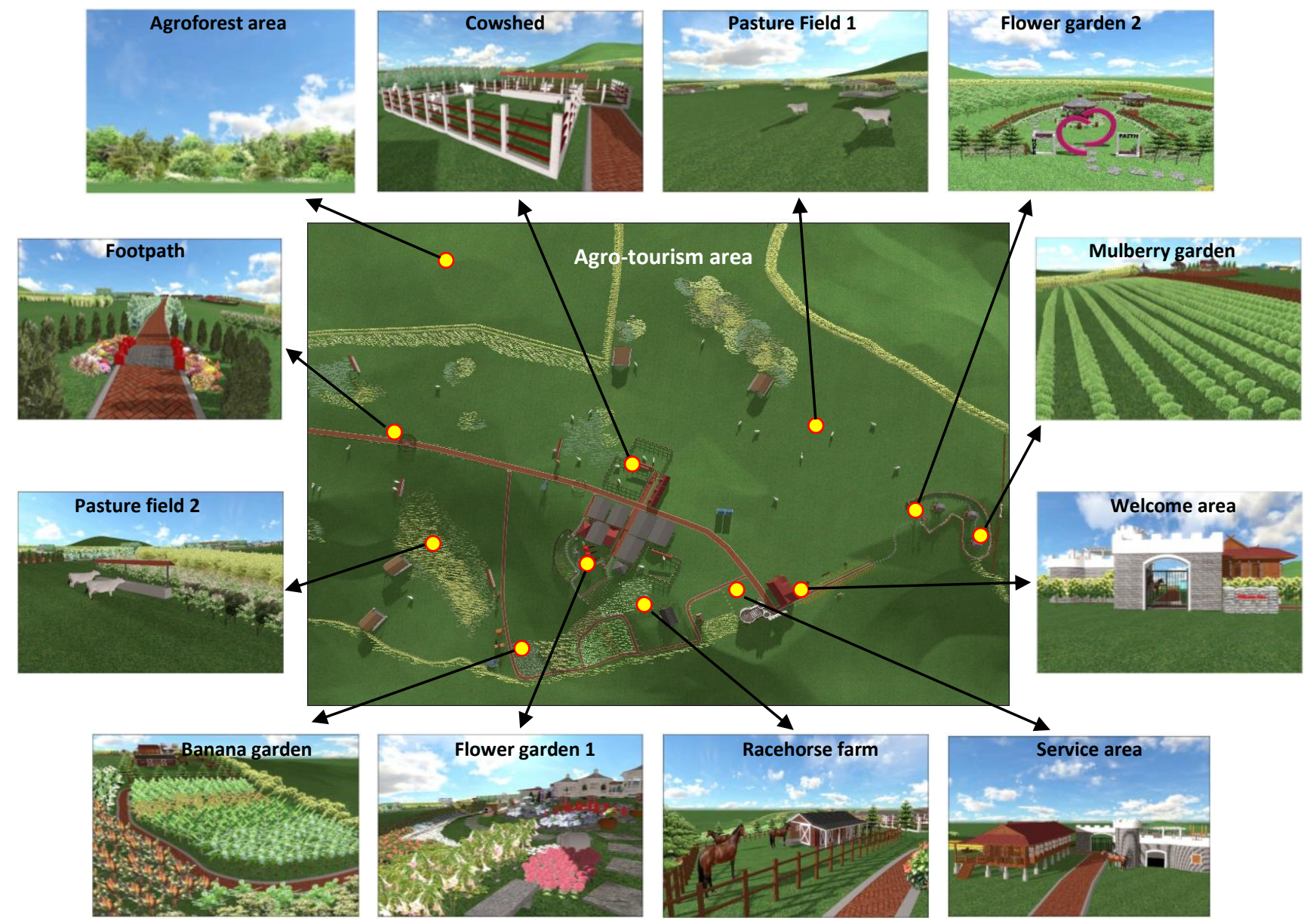

Figure 4. The green concept of landscape planning of Tampusu Agro-tourism, Minahasa District, North Sulawesi Province, Indonesia

Wedelia, creeping oxeye, or the trailing daisy, formerly known as Wedelia trilobata, but now as Sphagneticola trilobata, a beautiful, bright emerald-green creeper with bright yellow flowers, is an aggressive weed. It is one of spesies that causes problem because it is invasive in pasture fields. The IUCN has listed it in its 100 of the world's worst invasive alien species. S. campanulata, African tulip tree or ki acret, in the landscape also need to be controlled. This plant is very easy to breed, fast-growing even in a limited environment, and suppresses other types including endemic species of Sulawesi, namely Ficus minahassae and Ficus septica.

\section{Climate}

The maximum temperature of the area was $26.2^{\circ} \mathrm{C}$. This temperature is within the range of the human comfort zone. But for dairy cows commonly raised in Indonesia, the maximum temperature without temperature stress impact is $25^{\circ} \mathrm{C}$. Based on interview, dairy cows can produce the best milk at an average temperature of $20^{\circ} \mathrm{C}$ with a humidity of $55 \%$. Wind speeds were generally higher during the day than at night. When the weather was bad, the speed of wind caused problems, namely to damage the roof and livestock and visitors discomfort. Amelioration of microclimate is needed especially in pasture fields and around enclosure area.

\section{Access, facilities and utilities}

The site can be accessed using private vehicles or tourism buses but it was not bypassed local public transportation. Facilities and utilities that exist in the site included cow enclosure area, supporting buildings, guardhouse, and pavement for circulation routes. There were some severe damages to the facilities, for example, the roofs of several supporting buildings, gazebos, some cow pens, and parking lots. While other facilities were available but in very limited amounts and distribution, namely toilets and lighting, water storage tanks, and drinking places for cows. On the site, there were old circulation paths in the form of pavement. However, it is necessary to make a new design that connects agro-tourism zones. Information boards and steering boards are also needed. Water was available for livestock, toilets, and general area needs through groundwater pumping.

\section{Area management}

Visitors who came specifically as tourist can be said to be almost none. Some of the surrounding residents used part of the land to graze their livestock. Some workers raise 
cows and look after the entire area and receive monthly wages. There was no income from tourism activities nowadays. The development of the agro-tourism landscape needs to be synergized with other efforts such as linkage with other tourist destinations, transportation management, and promotion.

\section{The green concept of Tampusu agro-tourism}

Based on situation analyses of the existing site and the goal of Tampusu Agro-tourism, a landscape development concept is made (Figure 4). In addition to welcome area and public service area, the agro-tourism landscape is planned to have dairy farm (integrated farm area) as a core attraction, and a supporting attraction consisting of racehorse farm, flower gardens, mulberry garden, banana garden, and agroforest area (i.e. collection of endemic plant species). Dairy farm as the core attraction, is planned as an integrated farm area, which consists of pastures, cage complexes, living areas, and fences forage for animal feed, bioenergy processing from cow dung, water supply utilities, and supporting facilities. Indoor attractions are provided as an alternative tourist activity, utilizing agricultural and livestock products, also to anticipate bad weather. For example, ice cream making class, jam-making class, and indoor photo-booth. For the next stage, landscape planning and design stage, it is proposed to strengthen the theme of agro-tourism by creating uniqueness and by using supportive design (which includes supportive species and sometimes moreover, cultivar).

Referring to Tampusu Agro-tourism planning objectives, the benefits of agro-tourism that will be developed in this region are as follows: (i) improve environmental conservation, (ii) provide recreational and aesthetical values, (iii) increase community awareness in the field of agriculture broadly both in terms of cultivation activities and its products, (iv) being a place to develop, practice agricultural science and then to disseminate the discovery of appropriate technology in agriculture and approaches in the sustainable management of natural resources and the environment for agricultural development to the wider community with specific focus on organic animal husbandry and plant cultivation, (v) increase the productivity of land use, (vi) get economic profits, (vii) increase regional development, socially and physically.

After the landscape development concept planning was made, more specific concepts are formulated, one of them is the green/vegetation/plant concept. The basic green concept of Tampusu agro-tourism landscape is the composition and placement of plants that contribute to developing an interesting and satisfying, environmentally friendly and profitable agro-tourism area, under organic management system. Furthermore, the detailed green concept is based on several principles as follows.

\section{Concept of plant management}

Regarding organic theme in this agro-tourism area, more attention to plant cultivation which relies on ecological processes, biodiversity and natural cycles rather than the use of inputs with adverse effects (i.e. chemical pesticides, fertilizers): (i). Each plant has different characteristics and this has implications for different maintenance needs. (ii) In this green concept, it is prioritized to choose plants that do not require high maintenance intensity.

\section{Concept of species selection and utilization}

Species selection and utilization are based on functions that can contribute to the creation of good quality agrotourism landscape. Functions to be carried out by plants in the landscape are as follows.

Architectural function; relating to the use of plants in the landscape to fulfill their function as spatial elements, namely: (i) defines pathway, direction, e.g., Goodyera celebica, Thuja orientalis, (ii) barrier, sight screening or blocking, e.g., Racemobambos celebica, Cupressus sempervirens, (iii) canopy, e.g., F. minahassae, Pterospermum celebicum, Diospyros celebica, (iv) pedestal, e.g., Cynodon dactylon, Axonopus compressus.

Ecological function; where the use of plants in a landscape is intended to fulfill several functions in a reciprocal relationship with: (i) improving soil fertility, e.g., Centrosema pubescens, Sesbania grandiflora, Gliricidia sepium, (ii) microclimate modifier: creates a shade to withstand solar radiation, withstand strong winds, e.g., $T$. orientalis, $G$. sepium, $F$. minahassae, $C$. sempervirens, (iii) absorbs the stench and or produce a sweet fragnance, e.g., C. sempervirens, Clerodendrum fragnans, Sansevieria spp., (iv) reduce noise, e.g., I. celebica, Clerodendrum minahassae, (iv) absorb rainwater and puddles, e.g., R. celebica, Bambusa arundinacea ., Leucaena leucocephala), (v) retain groundwater, e.g., $F$. minahassae, Ficus benjamina, Tectona grandis, (vi) erosion control, e.g., Pennisetum purpureum, C. pubescens. A. compressus, Panicum maximum, (vii) conservation belt; considered because some parts of area borders the forest; use plants which are forest vegetations and physically blocking, for example, A. pinnata, $F$. benjamina, $R$. celebica, (viii) absorb pollutants, e.g., Spathiphyllum clevelandii, Scindapsus aureus, Sansevieria spp., Gerbera sp., (ix) support integrated pest management, e.g., Cymbopogon nardus, Tagetes erecta, Zinnia grandiflora, Cosmos caudatus, (x) role in biodiversity and endemism conservation; for examples Vatica celebica, C. minahassae, Myristica minahassae, Diospyros minahassae, Korthalsia celebica, Licuala celebica, Aquilaria beccariana, Kibatalia wigmanii, Lithocarpus celebica.

Production function; plant species to use as animal feedstock, for example, $M$. indica, A. compressus, $P$. purpureum, G. sepium; and for human consumptive needs, for example, Musa celebica, Musa acuminafe, M. indica.

Aesthetic function; for example $C$. minahassae, $I$. celebica, D. celebica, T. orientalis, $R$. celebica Phalaenopsis celebensis. Aesthetics of plants through color, shape, and texture of flowers, leaves, fruits, architectural stature, permanently or seasonally, both individually, in group with other species, or a single mass planting.

In terms of plant diversity and endemism, the green concept put priority to add as many as native species which serve as soft elements of the landscape, especially those with endemic status. Even some species will still be 
selected even though they do not have important social, economic, or (other) ecological values, as long as those species are endemic to Sulawesi and will well grow in the site. Also, special attention is given to control invasive alien plant species.

\section{Concept of arrangement and composition}

Composition of plants as: (i) foreground, e.g., Lantana camara, G. celebica, T. erecta, (ii) middle ground, e.g., Cosmos sulphureus, Hydrangea macrophylla, (iii) background, e.g., C. sempervirens, Agathis celebica, (iv) focal point, point of interest, e.g., Osmoxylon celebicum, $P$. celebensis.

Combining a variety of growth habits, which include trees (for example Elmerrillia ovalis), shrubs (for example L. camara), climbers (for example Ipomoea triloba, Strongylodon celebicus), and creepers (for example $A$. compressus, Ipomoea batatas).

\section{Concept of placement}

It is about conformity to the designation of zoning area. For example, for the welcome area, the species that suit are those with aesthetic functions with canopy not obstructing the view on the signboard and the gate, and not obstructing movement; for example Zinnia elegans, Macodes celebica, G. celebica. For cattle pasture, there is especially grass for feedstock equipped with legume plants. Species preferred by cattle include $A$. compressus, $P$. purpureum, Paspalum conjugatum, $C$. dactylon, Polytrias amuara, A. conyzoides, Panicum repens, $G$. sepium. Similar rules also apply to flower gardens, public service areas (shopping-eatingprayer areas), and green belt

\section{Concept of visual dynamic}

The conformity to the designation of zoning area will provide the dynamics of the place, or a space-based dynamics, namely the dynamics of design between one part to another part of the agro-tourism area. In addition, interesting dynamics of plants can be explored based on time, or a time-based dynamics.

\section{Discussion}

According to Nurisjah (2001) and Franjaya, Gunawan, and Mugnisjah (2013), agro-tourism or agricultural tourism is defined as a series of tourist activities that utilize the location or region and agricultural sector from the beginning of agricultural process to agricultural products in various systems, scales, and forms with the aim of expanding knowledge, understanding, experience, and recreation in agriculture. One application of crop diversity management is through diversification of food crops so that the demands of agricultural land for food do not only rely mostly on one or limited species (i.e. rice). The implementation of a food diversification policy needs appropriate strategies. Various strategies related to diversification of food consumption that can be implemented (Mburu, Koskey and Kimiti 2016) include: (i) Diversification of household businesses is directed toward increasing the income of producers, especially farmers, ranchers and small fishermen through the development of integrated farming; (ii) Diversification of business or food production and diversification of food consumption are carried out through the development of diversified integrated farming in the fields of food, plantations, animal husbandry, fisheries; (iii) Development of local food in accordance with regional wisdom and uniqueness to increase local food diversification; (iv) Human resource development in the field of food and nutrition is carried out through education, training and counseling in a more comprehensive manner. This study applies point no (iii). Actually, there has always been a source of carbohydrates in addition to rice, which is well known and has been a part of the daily lives of the people of North Sulawesi since long ago, such as sweet potatoes, cassava, bananas (goroho, tanduk, etc.), taro, and corn. But the trend shows that rice as a staple food and processed foods such as noodles and pasta as a substitute for staple foods are increasingly widespread among the younger generation. The current problem is that local food patterns tend to be abandoned, changing to rice and noodle or pasta patterns. The introduction of types, benefits, and cultivation of a variety of food plants while doing fun activities such as tourism will make it easier for them to absorb new insights and even later like alternatives to foodstuffs other than those they are used to consuming. Based on the right understanding, people more easily contribute to the preservation of plant diversity (Ruheza et al. 2013; Saroinsong and Kalangi 2016; Saroinsong and Kalangi 2018). The cost of the agro-tourism entrance ticket is planned to have taken into account the expenditure of bananas meal and snacks which will be given free to every visitor who has paid.

There are some reasons for proposing Banana Garden in the study area. Firstly, bananas require relatively less intensive maintenance, are easy to grow healthy without fertilizers and pesticides, so it fits the Tampusu agrotourism green concept. "Go organic" is actually a challenge of global agriculture which is looking for other biological and agrotechnical methods in order to meet the requirements of global food production (Feledyn-Szewczyk et al. 2016). The second rationale is banana plants in Indonesia, including North Sulawesi, have a variety of species, cultivar, shapes and benefits. Some types of bananas are eaten as fruit, and several other types as staple foods or complement and substitute of staple foods. Tampusu agro-tourism banana garden, besides introducing typical banana plants in North Sulawesi to foreign and regional tourists, for example, goroho banana, is also a gallery of the genetic diversity of bananas for all tourists including that are rarely found in the market or have rarely been planted and consumed. Lastly, for productivity to remain high, banana plants are usually cut off after harvesting fruit, leaves and flowers. This causes the availability of abundant banana stems so that it is potential as animal feed. Banana stems can be used as additional feed for cattle, both fresh and after the fermentation process (Thiasari and Setiyawan 2016). Based on the experience of local cattle ranchers, fresh banana stems are preferred especially when the air is hot enough. Whereas fermentation has the advantage of preserving large amounts 
of waste, besides increasing the quality of feed. In the fermentation process an increase in digestibility and the value of feed protein due to the use of inorganic nitrogen into microorganism cell proteins (Thiasari and Setiyawan 2016).

The benefits of Tampusu agro-tourism are similar to benefits of agro-tourism suggested by Tirtawinata and Fachruddin (1996), namely improving environmental conservation through environmental sustainability and ecosystem balance, maintaining hydrological functions to hold water reserves and preservation of germplasm of aquaculture plants, enhancing the aesthetic value, providing recreational value by providing supporting facilities and activities that can generate excitement in nature, increasing agricultural scientific activities, research and development, and obtaining economic benefits both for the region and the community.

One of the important things to consider in landscape planning is microclimate modification. In the context of the study area is especially to anticipate the sun exposure during the day, reduce glare, prevent high humidity, and anticipate strong winds through the use of soft elements and hard elements of the landscape. Plants canopy can reduce air temperature and solar radiation below and around them and can be used in design to ameliorate microclimate (Saroinsong et al. 2017; Mala et al. 2019). The function of plants in ameliorating microclimate in this landscape is to provide thermal comfort to human (especially visitors) and to maintain a healthy growth environment and support productivity of livestock.

Regarding the function of plants, many plants have more than one function. For example, Leucaena leucocephala (Lamk.( is an option in cattle grazing land as it has functioned as animal feed, creates shade and also absorbs standing water. Pine can be planted around the complex of dairy cows and calves as a view screening/blocking, physical barrier and windbreaker, and to reduce the bad odor from inside the cage to the outside and to reduce noise from outside. Murbei (Morus indica) is an option to be planted because the leaves are one of the feeds of cows which can increase milk production. Besides, the fruit can be eaten fresh or processed as jam which potential for tourist attraction of murbei picking and jam making classes, and can be planted on sloping land to reduce erosion. Casuarina equisetifolia is an option to be planted between grazing fields and circulation roads to limit the movement of livestock and visitors at the same time, and to produce natural fragrance, reduce noise, define pathway, increase soil aggregation by increasing soil granulation and porosity, and be a microclimate modifier. Besides, it does not cause problems if the leaves fall to the ground and are eaten by cows.

Furthermore, plant functions are related to factors that affect human comfort including circulation, climate, noise, smell, shape, safety, cleanliness, and beauty (Harefa et al. 2018). In this green concept, the contribution or role of plants to improve comfort that has implications for visitor satisfaction, namely: (i) Facilitate circulation, when used to direct/define pathway, (i) ameliorate microclimate, when used as a shade plant or windbreaker, (ii) noise control, (iii) reduce unpleasant odors and produces fragrant odors, (iv) support security, with hedges or dividers, (v) give beauty, through color, shape (fruit, flower, leaf, branch or overall plant shape), and texture.

Understanding visitors' perceptions of tourist areas can provide benefits for managers of tourist areas to improve facilities and improve services. The perception of visitors to the condition of attractions is something that is absolutely needed by the manager in an effort to develop tourist objects. Relating to green concept, the scenery is one that shapes visitors' perceptions about the tourist areas they visit (Botha et al. 2017). In utilizing a good view towards Mount Kasuratan, Mount Tampusu, and Lake Tondano, the function of plants is as the foreground. At the points with the best view outwards, the selection of plants is mainly to direct the view and frame a good view, rather than being a point of interest or blocking the view. To eliminate bad view, the function of plants is as sight blocking.

To avoid the herd moving to the area where the topography is dangerous (steep and very steep), or even falling into the land in the form of a basin, the green concept proposes to use plants that function as physical barriers for double protection to complete the fence. In some areas, plants are proposed to replace fence, in order to avoid rigid impressions. Related to tourism activities and production management, some plants that function as barriers will be used to limit the movement of herds towards the area with active tourism activities. In some places, there are also planned the use of plants that reduce odor so that the odor from cow dung does not disturb visitors, and the same time as sight screening. Around the complex of dairy cows and cows that are still breastfeeding, the use of plants is intended to provide isolation from the influence of noise and movement back and forth workers or visitors from the direction of the nearest circulation path.

Groups of plants that have production function in this landscape green concept are they which give advantage to agricultural and animal husbandry production activities. The plantation areas themselves (mulberry garden, pasture field, agroforest area, and banana garden) can also be used as tourism attraction zones.

Most plants in the study area are maintained following the green concept. However, $S$. campanulata needs to be controlled. W. trilobata (syn. S. trilobata) is also other species that need to be handled because of its invasiveness. There is special attention to control these two species. On the other side, the green concept proposes adding other species of plants as much as possible according to their function and site condition. Some endemic plants that are in accordance with the environmental conditions of this landscape will be planted either as production plants (animal feed and human consumptive uses), shade, barrier, ornamental plants and/or to control erosion or maintain hydrological systems. These plants namely D. celebica (kayu hitam), Ficus minahasae (langusei), Ficus septica (beringin), Dracontomelon dao (buah rao, pasifc walnut), Myristica celebica (n'timu atau darah-darah), K. celebica (rotan korthalsia), P. celebensis (anggrek bulan sulawesi), 
G. celebica (anggrek tanah), and M. celebica (pisang liar, pisang hutan). In the context of biological conservation, considering endemic species is also important. The management of species that are restricted to an area (i.e., endemic) is equally vital for environmental sustainability (Hens and Boon 2003).

In summary, the green concept contains principles in the management, selection, and use, composition and arrangement, placement, and visual dynamics of plants in Tampusu agro-tourism landscape. The process of formulating the green concept is supported by an understanding of the characteristics and purpose of landscape, plants' habitat, plants' characteristics, and plants' functions. The selection of plant species (including from both those that already exist and those that will be added) in the green concept of Tampusu agro-tourism is based on consideration of the plants' function in the landscape, with special consideration to the contribution in managing species diversity including endemic species in the area. Following the green concept in landscape planning, the function of vegetation planned in Tampusu agro-tourism is grouped into production, ecological, architectural, and beauty functions. This green concept has priority to add as many species as possible to serve as soft element of the landscape. Some species will still be selected even though do not have important social, economic, or (other) ecological values, with rationale to increase the biodiversity level of the landscape. Those species are endemic to Sulawesi with their habitat requirements are suitable with the site. Invasive alien plant species is to be controlled. The landscape planning process in this study was carried out with consideration of translating the theory of diversity conservation specifically the concept of plant diversity management. Assuming that the green concept will be continued into the landscape plan, and then the landscape plan will be realized through the implementation of Tampusu agro-tourism development, so that the management of plant diversity can be truly applied. Landscape planning process, specifically developing green concept, has an important role in translating the concept of plant biodiversity management into concrete actions.

\section{ACKNOWLEDGEMENTS}

This research was supported by Sam Ratulangi University, Menado, Indonesia.

\section{REFERENCES}

Ahmadi F, Sadeghi AR, Eskandarinezhad AR. 2016. Ecological quality improvement of urban landscapes with emphasis on sustainable development principles case study: River of Darabad Valley, Tehran, Iran. Eur J Sustain Develop 5 (3): 91-102.

Altieri MA. 1999. The ecological role of biodiversity in agroecosystems. In: Invertebrate Biodiversity as Bioindicators of Sustainable Landscapes. Elsevier, The Nederlands

BAPPENAS. 2004. Wilayah Kritis Keanekaragaman Hayati di Indonesia, Bappenas, Jakarta. [Indonesian]

Botha Y, Saroinsong FB, Pollo HN. 2017. Persepsi pengunjung terhadap pengelolaan kawasan wisata Bukit Kasih Kanonang. Cocos 1 (6): 1-6. [Indonesian]
Bryan BA, Raymond CM, Crossman ND, Macdonald DH. 2010. Targeting the management of ecosystem services based on social values: Where, what, and how? Landsc Urban Plann 97 (2): 111-122.

Budiharta S, Widyatmoko D, Irawati, Wiriadinata H, Rugayah, Partomihardjo T, Ismail, Uji T, Keim AP, Wilson K. 2011. The processes that threaten Indonesian plants. Oryx 45: 172-179.

Ciolac R, Adamov T, Iancu T, Popescu G, Lile R, Rujescu C, Marin D. 2019. Agritourism-A sustainable development for improving the health of rural settlements. Case Study: Apuseni Mountains Area. Sustainability 11: 1467-1491.

Feledyn-Szewczyk B, Kuś J, Stalenga J, Berbeć AK, Radzikowski P. 2016. The role of biological diversity in agroecosystems and organic farming. In: Organic Farming-A Promising Way of Food Production. IntechOpen Ltd., London.

Franjaya EE, Gunawan A, Mugnisjah WQ. 2013. Desain lanskap pertanian terpadu sebagai wahana pendidikan dan wisata pertanian. Jurnal Lanskap Indonesia 5 (1): 7-15. [Indonesian]

Frison EA, Cherfas J, Hodgkin T. 2011. Agricultural biodiversity is essential for a sustainable improvement in food and nutrition security. Sustainability 3 (1): 238-253.

Harefa AS, Naibaho PDR, Rahmawati AL. 2018. Persepsi penghuni terhadap kenyamanan beraktivitas di ruang terbuka perumahan. Alur 1 (1): 37-46. [Indonesian]

Hens LK, Boon E. 2005. Causes of biodiversity loss: a human ecological analysis. Vrije Universiteit Brussel, Brussel.

Imboden C, Gross D, Meynell PJ, Richards D, Stalmans M. 2010. Biodiversity management system: proposal for the integrated management of biodiversity at Holcim Sites. IUCN, Geneva.

Mala YP, Kalangi JI, Saroinsong FB. 2019. pengaruh ruang terbuka hijau terhadap iklim mikro dan kenyamanan termal pada 3 lokasi di Kota Manado. Eugenia 24 (2): 52-63. [Indonesian]

Mastronardi L, Giaccio V, Giannelli A, Scardera A. 2015. Is agritourism eco-friendly? A comparison between agritourisms and other farms in Italy using farm accountancy data network dataset. Springerplus 4: 590-602.

Mburu SW, Koskey G, Kimiti JM, Ombori O, Maingi JM, Njeru EM. 2016. Agrobiodiversity conservation enhances food security in subsistence-based farming systems of Eastern Kenya. Agric Food Secur 5: 19. DOI 10.1186/s40066-016-0068-2

Muhammad M, Hamzah A, Yassin SMd, Samah BA, Tiraieyari N, D’Silva JL. Shaffril HAM. 2016. environmental issues of agrotourism: The views of coastal community in Malaysia. Soc Sci 11 (3): 192-195.

Nurisjah S. 2001. Pengembangan kawasan wisata agro (Agrotourism). Buletin Tanaman dan Lanskap Indonesia 4 (2): 20-23. [Indonesian]

Ruheza S, Mattee ZA, Chingonikaya EE, Kilugwe Z. 2013. Integration of the indigenous knowledge system (IKS) for sustainable management and use of biodiversity in South Nguru Mountain forest, Tanzania: the influence of socio-economic and political factors. J Sustain Dev Afr 15 (8): 94-114.

Saroinsong FB, Kalangi JI, Babo P. 2017. Redesain ruang terbuka hijau Kampus UNSRAT berdasarkan evaluasi kenyamanan termal dengan indeks disc. Eugenia 23 (2): 62-75. [Indonesian]

Saroinsong FB, Kalangi JI. 2016. Teknik pengelolaan sumber daya alam untuk konservasi di area pemukiman. ABDIMAS: Jurnal Pengabdian kepada Masyarakat, 9 (1): 15-33. [Indonesian]

Saroinsong FB, Kalangi JI. 2018. Diseminasi pengelolaan rth pemukiman untuk meningkatkan biodiversitas flora. Edupreneur: Jurnal Pengabdian kepada Masyarakat Bidang Kewirausahaan 1 (3): 54-70. [Indonesian]

Sasaoka M, Laumonier Y. 2012. Suitability of local resource management practices based on supernatural enforcement mechanisms in the local social-cultural context. Ecol Soc 17(4): 6. DOI: 10.5751/ES-05124170406.

Thiasari N, Setiyawan AI. 2016. Complete feed batang pisang terfermentasi dengan level protein berbeda terhadap kecernaan bahan kering, kecernaan bahan organik dan TDN secara in vitro. Jurnal Ilmu-Ilmu Peternakan 26 (2): 67-72. [Indonesian]

Tirtawinata MR, Fachruddin L. 1996. Daya tarik dan pengelolaan agrowisata. Penebar Swadaya, Jakarta. [Indonesian]

Verburg PH, et al. 2015. Land system science and sustainable development of the earth system: A global land project perspective. Anthropocene 12: 29-41.

Wascher D, Haines-Young R. 2009. Assessing landscape functions with broad-scale environmental data: insights gained from a prototype development for Europe. Environ Manag 44: 1099-1120. 